\title{
Young ones having younger ones: Adolescent mothers' repeated pregnancy experiences in the Philippines
}

\author{
Adreal Denver Monterona ${ }^{1^{*}}$ \\ ${ }^{1 *}$ Commission on Population and Development, Region III, Philippines \\ * Corresponding author \\ E-mail address: denver.monterona@popcom.gov.ph \\ DOI: https://doi.org/10.21107/sml.v3i2.8666
}

\begin{tabular}{|c|c|}
\hline Article Info & Abstract \\
\hline $\begin{array}{l}\text { Keywords: } \\
\text { Repeated } \\
\text { adolescent } \\
\text { pregnancy } \\
\text { Reproductive } \\
\text { health } \\
\text { Gender } \\
\text { Filipino families }\end{array}$ & $\begin{array}{l}\text { Many adolescents in the Philippines are not only getting pregnant under the } \\
\text { age of } 20 \text { but are also having repeated pregnancies. Several local studies have } \\
\text { determined the prevalence and the correlates of repeated pregnancies among } \\
\text { Filipino adolescents, but the qualitative contexts in which these pregnancies } \\
\text { are occurring are unclear yet are important for program development. } \\
\text { This paper discusses some qualitative data drawn from experiences of } \\
\text { youth who have had repeated pregnancies as a result of a qualitative study } \\
\text { that employed the phenomenological and the narrative methodological } \\
\text { approach. The study made use of data collected through individual in-depth- } \\
\text { interviews with adolescents from the province of Pampanga, Philippines } \\
\text { who have experienced more than one pregnancy from ages } 15 \text { to 19. Over- } \\
\text { all themes on the experiences of young mothers include positivity amid } \\
\text { within the negativity and old connections, new unions. Found to be both a } \\
\text { biological and social phenomenon, repeated adolescent pregnancy heightens } \\
\text { both personal and social experiences of the young mother while it involves } \\
\text { gender, forming and rebuilding of families as well as local context, and as } \\
\text { such validates the need for further research. }\end{array}$ \\
\hline
\end{tabular}

Citation suggestion:

Monterona, A. D. (2020). Young ones having younger ones: Adolescent mothers' repeated pregnancy experiences in the Philippines. Simulacra, 3(2), 153-164. https://doi.org/10.21107/sml.v3i2.8666

Received 25 September 2020; Received in revised form 10 October 2020; Accepted 14 October 2020; Published online 25 November 2020. 


\section{Introduction}

Defined as pregnancy among women aged 19 and below (Singh \& Darroch, 2000), adolescent pregnancy has been associated with risks involving poor maternal and child health (Wickrama \& Lorenz, 2002; Grundy \& Tomassini, 2005; Raneri \& Wiemann, 2007; Lavin \& Cox, 2012) and socio-economic disadvantages (Lavin \& Cox, 2012; Sonfield, et al., 2014). While it is declining among high-income countries (Santelli, et. al., 2017), developing and underdeveloped countries have recently reported high early pregnancy cases (Sedgh, et. al., 2015; Bearak, et. al., 2018). In the Philippines, the national demographic and health surveys within the last ten years have shown a steady increase of almost 10 percent on pregnancy cases among women aged 15 to 19 years old (Herrin, 2016) and current public health reports have cited incidences of adolescent pregnancy as low as ten years old (Arumpac, 2012; Alimondo, 2018).

Contributory to increasing early pregnancy trends in the Philippines is the phenomenon of repeated adolescent pregnancies. This phenomenon is defined as a young mother's subsequent pregnancy between the ages of 10 and 19 (Maravilla, et al., 2017). Found to double or triple the risks brought by first-time childbirths among young mothers (Mphatswe, et. al., 2016; Maravilla, et. al., 2017), repeated adolescent pregnancy cases in the country had an increase among young women from 2000 to 2010 as reported by the Philippine Statistics Authority (Morales, 2013) and are reported to have close birth intervals (Natividad, 2014).

Currently, program and policy efforts in the Philippines are focused on addressing first-time teenage pregnancy. However, the increasing trends of repeated pregnancies among young Filipino mothers in only a decade also warrant necessary interventions. For program and policy development, available local studies have determined the prevalence and correlates of repeated adolescent pregnancy. Hence, in order to complement these quantitative findings on repeated adolescent pregnancy, there is a need for clear qualitative contexts on the phenomenon.

As such, this paper provides some qualitative data on young Filipino mothers' personal and social experiences on repeated pregnancy based on a study conducted through a phenomenological perspective. The said study, anchored on the Rainbow Model of Health which highlights the interconnection between individuals and environments in identifying the determinants of their health (Dahlgren \& Whitehead, 1991), was conducted through a phenomenological research design with a narrative methodological approach. This paper thus presents the study's findings on 1) the personal experiences of adolescent who have had repeated pregnancies, 2) the social experiences of these adolescent, and 3) overall themes on these experiences.

The mentioned study described repeated adolescent pregnancy through narratives of Filipino mothers who have had more than one pregnancy upon reaching the age of 19 while residing in the province of Pampanga. The selection of the province was based on reports that Pampanga is one of the areas in the country with the highest cases of teenage pregnancy according to recent public health reports. Thus, the study excluded young mothers who live in other provinces, young mothers who have experienced only one instance of pregnancy, young fathers, the young mothers' parents, community workers 
and members who interact with young mothers, as well as the young mothers' peers.

\section{Method}

The study used a non-probability purposive sampling procedure through individual interviews conducted among 15 young mothers. Data were collected with the assistance of the provincial population office using an interview guide using one main question ("can you recount your experiences as a young mother from the time you had your first baby up to the end of your repeated pregnancy?"). Pretested to ensure instrument reliability, the interview guide was initially constructed in English and translated into the participant's language (Kapampangan or Tagalog). Data collected were then translated into English. To inhibit sex-related bias, the interview was conducted mostly in a private area, with the researcher accompanying the interviewer and participant during the process, except for cases when the participant opted to proceed with only the population workers present. Participants were asked for both verbal and written consent to ensure voluntary participation and informed consent. For confidentiality, anonymity, and data privacy, participants were also asked to provide pseudonyms to be used for identification during data analysis. Furthermore, all accomplished forms and voice recordings were stored solely by the researcher and used only for transcription, coding, and analysis.

This paper presents one of two data analyses used in the study. Data were initially analyzed through narratives. The other, which is presented in this paper, was the thematic analysis to come up with overall themes. For both analyses, the English translation of the interviews was subjected to coding. For reliability, source-checking was conducted among the participants after the completion of data analysis, through another face-to-face interview.

\section{Results and Discussion}

\section{Participants' profiling information}

Participants for this study are profiled based on their level of education, pregnancy spacing, family set-up, and living arrangements. Young mothers who were part of this study had received some form of formal education prior to their first pregnancy, with young mothers attaining education ranging from grades 6 to 12, but had to stop schooling when they had their first pregnancy and were not able to continue their studies upon their repeated pregnancy. They have had repeated pregnancies less than three years after their first child, with their repeated pregnancies occurring while they were 19 years old or younger. They usually enter into common-law marriages with their partner during their first pregnancy and decide to get married after their repeated pregnancy. They mainly rely on their partner's income although they also look for alternative sources of income such as online selling while residing in the households of their partners' families.

\section{Personal experiences of young mothers on both pregnancies}

Personal experiences of adolescent mothers on both first and repeated pregnancies are enumerated in Table 1. Common experiences among young mothers on both pregnancies are having a difficult life brought by pregnancy concerns and positive perspectives on having a baby 
and motherhood. Young mothers who had a difficult life brought by pregnancy concerns are best described by the following statement:

"Mas lalo pong humirap yung buhay. Kahit na pangalawa ko na pong baby to, mahirap pa rin po magbuntis. Mahina po yung kapit ng bata sa matris ko po. Muntik na po ako manganak ng 7 months pa lang yung baby." (Life got harder. Even if it's my second time to get pregnant, pregnancy was still rough. My womb was weak. I almost gave birth prematurely when my baby was only 7 months in the womb).

Other common experience among young mothers' personal experiences is the positive perspective on having a baby on their first pregnancy, and the positive perspective on motherhood on their repeated pregnancy. These can be described by the following statement:

"Sibukan kung ali paapektu. Ing gewa ku, mas sinaup kupa kareng obra bale at meging tahimik mu kabang mabuktut ku king kadwa kung anak at kabang babanten ke ing pangane. Ita mu rin ing meging rasun kaya ku sinubuk meg-online selling, para maski pakananu makasaup $k u$ king pamilya mi kabang titipun ku naman para kareng check-up at panulu ku." (I try to not let [my pregnancies] affect me. Instead, I try to help with the household chores and live with them peacefully while I was pregnant with my second baby and taking care of my firstborn. That's also why I tried online selling so I could somehow help with the expenses while saving for my check-ups and medications).

Personal experiences that are uniquely encountered by the young mothers on their first pregnancy alone include the feeling of neglect from their families before being pregnant, knowledge about pregnancy and married life, self-support, and having a previously carefree life. On the other hand, personal experiences that these young mothers exclusively encountered during their repeated pregnancy include seeing their kids as their source of happiness. This is best described by the statement:

"Makananu man, dininan na ku pung adwang anak. Deng aliwa kasi maski matwa na la e la pa magkayanak. Para kanaku pu, blessing ya pu." (Whatever has happened, the truth is that I was given two children. There are others who are already old but still have no children. For me, that's a blessing).

\section{Social experiences of young mothers on both pregnancies}

Social experiences of adolescent mothers on both first and repeated pregnancies are enumerated in Table 2. Common experiences in the young mothers' first and second pregnancies include the disapproval and disappointment of their own family, the new role of the partner's family in the mother's life, the partner's dominance over the young mother, and judgment from the community. Young mothers' experiences on the disapproval and disappointment of their own family are described by the following statement:

"Decision po kasi ng both parents namin na huwag po muna kaming magsama. Para po sana makapag-focus sa pag-aaral. Pero ayun po, nabuntis po uli ako ng hindi planado. Si mama po tahimik lang, pero si papa nagalit uli po. Kasi po sabi niya sa akin mahirap po magkaroon ng anak." (It was our parents' decision that we wouldn't stay together that time so we could focus on our studies. But then, I got pregnant again, it wasn't planned. Mama was just quiet that time, but papa was angry again, because he told me that having kids is difficult). 
Table 1. Personal experiences of adolescent mothers on repeated pregnancies

\begin{tabular}{|c|c|c|}
\hline EPISODE & EXPERIENCES & ASSOCIATED THEMES \\
\hline \multirow[t]{6}{*}{$1^{\text {st }}$ pregnancy } & $\begin{array}{l}\text { - No knowledge of what's going to happen } \\
\text { - Unplanned pregnancy } \\
\text { - Fear of what's next }\end{array}$ & $\begin{array}{l}\text { Little knowledge about pregnancy } \\
\text { and married life }\end{array}$ \\
\hline & $\begin{array}{l}\text { - Pregnancy complications } \\
\text { - Miscarriage } \\
\text { - Difficult pregnancy } \\
\text { - Risky pregnancy } \\
\text { - Pregnancy-related cravings (paglilihi) }\end{array}$ & $\begin{array}{l}\text { Difficult life brought by pregnancy } \\
\text { concerns }\end{array}$ \\
\hline & $\begin{array}{l}\text { - Longing for attention } \\
\text { - Difficult life } \\
\text { - Sad childhood } \\
\text { - Running away from home }\end{array}$ & Feeling of neglect \\
\hline & $\begin{array}{l}\text { - Living independently } \\
\text { - Starting to working early } \\
\text { - Separation from family }\end{array}$ & Self-support \\
\hline & - Happiness to have a baby & Positive Perspective on having a baby \\
\hline & - Life was carefree before & Previously carefree life \\
\hline \multirow[t]{3}{*}{ Repeated pregnancy } & $\begin{array}{l}\text { - Life goes on } \\
\text { - Second pregnancy was easier } \\
\text { - No regrets about pregnancies }\end{array}$ & Positive perspective on motherhood \\
\hline & - Having own kids is a source of happiness & Kids as a source of happiness \\
\hline & $\begin{array}{l}\text { - Life got harder because of pregnancy complications } \\
\text { - Unplanned pregnancy } \\
\text { - "Too soon" pregnancy made it difficult } \\
\text { - Far from previous lifestyle } \\
\text { - Want for abortion }\end{array}$ & $\begin{array}{l}\text { Difficult life brought by pregnancy } \\
\text { concerns }\end{array}$ \\
\hline
\end{tabular}

Another common experience is the new role of the partner's family in the mother's life described by the following statement:

“Ngayon, natanggap ko na pagiging mature ko. Pero nahihirapan po ako makisama sa parents ng asawa ko po. Lalo po nung pangalawang pagbubuntis ko po kasi po kinakalat ng mga inlaw ko na malandi raw ako." (I've accepted that I have become mature. But I still am having trouble dealing with my partner's parents. Particularly when I was pregnant for the second time, they spread rumors about me that I was a flirt).

Another social experience that manifested in pregnancies involved the partner's dominance over the adolescent mother described by the following statement:
"Ala kaming gagamitan a [family planning method] ngeni kasi e pu bisa ing asawa ku na mag-pills $k u$. Pero eku na talaga bisang mabuktut pang pasibayu kasi masakit na atin na kang adwang anak." (We don't use [any family planning method] now because my husband doesn't want me to use pills. But I really don't want to get pregnant again because it's already hard to have two children).

Judgments from the community is the last social experience among adolescent mothers in both of their pregnancies, described by the following statement:

"Kapag mipapalibut ku keng lugar mi, daramdaman kula ding aliwang siping bale mi sisitsitan kung pakananu ku kanu kalandi uli na ning mebuktut ku king anak a edad." (Whenever I walk in our neighborhood, I hear other 
Table 2. Social experiences of adolescent mothers on repeated pregnancies

\begin{tabular}{|c|c|c|}
\hline EPISODE & EXPERIENCES & ASSOCIATED THEMES \\
\hline \multirow[t]{12}{*}{$1^{\text {st }}$ pregnancy } & - Relationship kept secret from family & Hidden relationship \\
\hline & $\begin{array}{l}\text { - Partner has temporary jobs } \\
\text { - Supportive partner }\end{array}$ & Partner's role as financial source \\
\hline & $\begin{array}{l}\text { - Older partner } \\
\text { - Forced by partner to elope } \\
\text { - Forced by boyfriend for sex } \\
\text { - Partner wanted abortion }\end{array}$ & Partner's dominance over the young mother \\
\hline & $\begin{array}{l}\text { - Concern for baby's health } \\
\text { - Unplanned married life }\end{array}$ & Unexpected change of family role \\
\hline & $\begin{array}{l}\text { - Guidance from partner's family } \\
\text { - Financial support from partner's family } \\
\text { - Being talked about by partner's parents }\end{array}$ & New role of partner's family in mother's life \\
\hline & $\begin{array}{l}\text { - Broken family } \\
\text { - Family has scarce resources } \\
\text { - Parents experienced early marriage } \\
\text { - Absence of parents }\end{array}$ & Poor \& dysfunctional family of origin \\
\hline & $\begin{array}{l}\text { - Eldest of three children } \\
\text { - Eldest of five }\end{array}$ & Eldest among siblings \\
\hline & $\begin{array}{l}\text { - Lives with mother } \\
\text { - Living with mother and siblings } \\
\text { - Lives with guardian } \\
\text { - Financial support from mother }\end{array}$ & Dependency on family \\
\hline & $\begin{array}{l}\text { - Only among siblings to be single } \\
\text { - Pushed by mother to live with partner }\end{array}$ & $\begin{array}{l}\text { Family influences on acceptance of } \\
\text { motherhood }\end{array}$ \\
\hline & $\begin{array}{l}\text { - Parents were disappointed } \\
\text { - Father was angry } \\
\text { - Parents got mad at first } \\
\text { - Family was angry }\end{array}$ & $\begin{array}{l}\text { disapproval and disappointment of their } \\
\text { own family }\end{array}$ \\
\hline & $\begin{array}{l}\text { - Met partner at school } \\
\text { - Met partner at work } \\
\text { - Met partner through friends }\end{array}$ & Institutional role in developing relationships \\
\hline & $\begin{array}{l}\text { - Labeled as "flirt" } \\
\text { - Pregnancy was discussed by neighbors } \\
\text { - Friends drifted away } \\
\text { - Wondering friends }\end{array}$ & Judgment from the community \\
\hline \multirow[t]{4}{*}{ Repeated pregnancy } & $\begin{array}{l}\text { - Partner works far from home } \\
\text { - Only the partner had a job } \\
\text { - Partner wants more kids } \\
\text { - Partner is against Family Planning }\end{array}$ & Partner's dominance over the young mother \\
\hline & $\begin{array}{l}\text { - Partner's parents were affected } \\
\text { - Support from partner's family } \\
\text { - Problems with partner's parents } \\
\text { - Being talked about by partner's parents } \\
\text { - Acceptance from partner's family }\end{array}$ & New role of partner's family in mother's life \\
\hline & $\begin{array}{l}\text { - Father got angry } \\
\text { - Mother was angry } \\
\text { - No help from family } \\
\text { - Not able to financially help family } \\
\text { - Family disapproves of the partner }\end{array}$ & $\begin{array}{l}\text { Disapproval and disappointment from } \\
\text { family }\end{array}$ \\
\hline & $\begin{array}{l}\text { - Being talked about by neighbors } \\
\text { - Labelled as "flirt" }\end{array}$ & Judgment from the community \\
\hline
\end{tabular}


residents gossiping how I was too much of a flirt because I already was pregnant at that age).

\section{Overall themes}

From the results of the study, overall themes that emerged from the young mothers' personal and social experiences include positivity amid the negativity and old connections, new unions, respectively.

\section{Positivity amid the negativity}

The young mothers view early pregnancy as an escape from their perceived negative circumstances which include feelings of loneliness and the need to take care of themselves due to the physical or emotional absence of their parents. This provides depth to statements of Berglund, et. al. (1997), Palacios \& Kennedy (2010), Gyan (2013), Van Zyl (2014), and Galabo \& Gempes (2017) that young mothers who have already begun pregnancy have had "a desire for affection" and "feelings of powerlessness" or physical or emotional distress due to either "chaotic childhoods" or poor parenting. Furthermore, these young mothers view their newborn children or their newly formed family as potential sources of happiness and positivity, corroborating with findings of Kalmuss \& Namerow (1994), Montgomery (2002), Boardman, et. al. (2006), and Rowlands (2010) on the positive attitudes of adolescent mothers towards their pregnancies.

On the other hand, these experiences of adolescent mothers on repeated pregnancies with mothers enter motherhood on their first pregnancy with little knowledge about pregnancy and married life, agreeing with statements by Lehana \& Van Rhyn (2003), Bennett, et. al. (2013), and Van Zyl, et. al. (2015) on adolescent pregnancy, education, and parenting skills. Their little knowledge on reproductive health makes them unprepared to address pregnancy complications which affect not only their health but their unborn babies as well, validating findings on poor maternal and child health from Grundy \& Tomassini (2005), Raneri \& Wiemann (2007), Wickrama \& Lorenz (2002), and Lavin \& Cox (2012). These complications exist even more so during repeated pregnancies, with experiences of adolescent mothers on repeated pregnancies mothers having riskier pregnancies in spite of the knowledge gained through their first pregnancies, making life more difficult in terms of health and living conditions. This substantiates the quantitative outcomes of Mphatswe, et. al. (2016) and Maravilla, et. al. (2017) that repeated pregnancies double the health and economic risks of experiences of adolescent mothers on repeated pregnancies mothers.

\section{Old connections, new unions}

Usually the eldest among the siblings, these young mothers are members of broken or dysfunctional households of big family sizes living in poor economic conditions with high economic dependency and low emotional support. This profile pattern agrees with findings from Acharya, et. al. (2010), Azevedo, et. al. (2012), and PenmanAguilar (2013) on adolescent pregnancy and poor socio-economic conditions. Upon their first pregnancy, these young mothers drop out of school and move into their partners' families having similarly poor economic circumstances, accepting their new roles as young mothers and an extension of another family. This barrier to the young mothers' continued education corroborates with statements from Lehana \& Van Rhyn (2003) and Wilson-Mitchell, et.al. (2014). 
The occurrence of repeated pregnancy also signifies an additional member of their household and the continuation of their poor living conditions providing depth to findings of Kalmuss \& Namerow (1994), Gillmore, et. al. (1997), Boardman, et. al. (2006) and Mollborn \& Jacobs (2012) on changing family structure and "unmet basic needs" with the occurrence of repeated pregnancies. Yet, looking back at theyoung mothers' narratives, one reason that young mothers lead to early pregnancy is the absence of family support and attention which influence these young mothers to find other connections such as engaging in romantic relationships in school, at their workplace, or even among peers. This scenario further provides more details to findings by Gillmore, et. al. (1997), Boardman, et. al. (2006), Hermann (2006), James, et. al. (2012), and Gyesaw \& Ankomah (2013) on the impact of family support in preventing adolescent pregnancy. The absence of guidance expected from their families of origin also increases the young mother's possibility of being forced by their partners to engage in unprotected sex which in turn also increases the possibility of early pregnancy. This situation further provides details as to what Van Zyl (2014) meant by powerlessness in adolescent pregnancy. This dominance of the male partners over the young mothers is further evidenced in the former's decision to be the breadwinner while the latter go through their repeated pregnancy, which corroborates with Mkhwanazi (2010), Ngabaza (2011) and Morrell, et.al. (2012) on control, regulation and power among young households.

\section{Lessons drawn from the young mothers' repeated pregnancy experiences}

Throughout the study, repeated adolescent pregnancy is seen to have a ripple effect. This effect is seen from the young mothers to her social layers: it starts in the young mother and involves her partner, and it progressively reaches out to their families, and their communities.

As a ripple, repeated pregnancy among adolescents is also an effect of a starting point: the first pregnancy. Thus, to understand this phenomenon is to understand first how firsttime pregnancy manifests in the mentioned social layers. Doing so provides context to a more in-depth understanding of how repeated adolescent pregnancy is lived by the young mother and her social layers. This perspective also validates that the outcomes of the lived experiences of adolescent mothers during their first pregnancies are heightened when they experience repeated adolescent pregnancy.

But then, just as a ripple, while these repeated pregnancies may have existed due to first-time adolescent pregnancy, the lack of knowledge on reproductive health also emerged as a starting point to both. These adolescent mothers went through pregnancy with little knowledge of reproductive health, which only brings one to link the lack of comprehensive education on reproductive health to the existence of repeated pregnancy in adolescent mothers.

Moreover, as the ripple spreads out, it also results to many unexpected layers that also need to be looked into. And in the context of this present study, these layers are forces that emerged upon data analysis that are yet to be studied further. Case in point, the topic of gender surfaced among the experiences of young mothers with the dominance of their partners over them. Furthermore, the forming and rebuilding of families that the young mother is part of leads one to ask how further these layers influence, and are influenced by, repeated adolescent 
pregnancy. Moreover, the perception of having children as blessings in spite of the hardships that come with it presents a unique Philippine context as another layer that may provide more insights to the phenomenon.

\section{Conclusion}

Through this study, repeated adolescent pregnancy experiences are described as a personal and social phenomenon. The study not only presented the young mothers' experiences but also the underlying involvement of their social layers. Both personal and social experiences on the young mothers' first pregnancy are heightened during their repeated pregnancies. The amplified pregnancy risks, additional members to their loop of families, as well as limited living conditions make the young mothers' experiences more difficult in spite of their positive attitudes on motherhood underscored by the lack of comprehensive reproductive health education and information. Therefore, repeated adolescent pregnancy is both a biological and a social phenomenon based on both personal and social experiences.

Unexpected dimensions also surfaced from the study including gender, forming and rebuilding of families, and the unique Philippine context of which these dimensions are anchored on. These present more areas on repeated adolescent pregnancy that need to be studied. As such, it is recommended to contribute further to the knowledge on repeated adolescent pregnancy through more research covering these areas to corroborate the findings of this study and to contribute to the theoretical development of the phenomenon. There is also a need for other studies which take into accounts the inclusion of many other dimensions that were excluded from this study, such as focusing into the perspectives of adolescent mothers' personald and social layers, widening the geographical locus, as well as considering comparative study of adolescent mothers who have had only one pregnancy.

\section{Declaration of Ownership}

This article is our original work.

\section{Conflict of Interest}

There is no conflict of interest to declare in this article.

\section{Ethical Clearance}

This study was approved by the institution.

\section{References}

Acharya, D. R., Bhattaria, R., Poobalan, A. S., Van Teijlingen, E., \& Chapman, G. N. (2010). Factors associated with teenage pregnancy in South Asia: A systematic review. Health Science Journal, 4(1), 3-14.

Alimondo, L. (2018, July 12). DOH: Risk of death high among pregnant teenagers. Retrieved from https://www.sunstar. com.ph/article/1752486

Arumpac, A. (2012, January 01). The youngest mother in Philippine history. Retrieved from http://www.gmanetwork.com/ news/publicaffairs/frontrow/266130/theyoungest-mother-in-philippine-history/ story/

Azevedo, J. P., Favara, M., Haddock, S. E., López-Calva, L. F., Muller, M., \& Perova, E. (2012). Teenage pregnancy and opportunities in Latin America and the Caribbean: on teenage fertility decisions, poverty and economic achievement. World Bank. 
Bearak, J., Popinchalk, A., Alkema, L., \& Sedgh, G. (2018). Global, regional, and subregional trends in unintended pregnancy and its outcomes from 1990 to 2014: estimates from a Bayesian hierarchical model. The Lancet Global Health, 6(4), e380-e389. https://doi. org/10.1016/S2214-109X(18)30029-9

Bennett, I. M., Frasso, R., Bellamy, S. L., Wortham, S., \& Gross, K. S. (2013). Preteen literacy and subsequent teenage childbearing in a US population. Contraception, 87(4), 459-464. https://doi. org/10.1016/j.contraception.2012.08.020

Berglund, S., Liljestrand, J., Marín, F. D. M., Salgado, N., \& Zelaya, E. (1997). The background of adolescent pregnancies in Nicaragua: A qualitative approach. Social Science \& Medicine, 44(1), 1-12. https:// doi.org/10.1016/S0277-9536(96)00084-6

Boardman, L. A., Allsworth, J., Phipps, M. G., \& Lapane, K. L. (2006). Risk factors for unintended versus intended rapid repeat pregnancies among adolescents. Journal of Adolescent Health, 39(4), 597-e1. https:// doi.org/10.1016/j.jadohealth.2006.03.017

Dahlgren, G., and M. Whitehead. Rainbow model of health. European Health Policy Conference: Opportunities for the future. Vol. 11. 1991.

Galabo, N., \& Gempes, G. P. (2017). Teenage pregnancy in secondary schools: A multiple case study. International Journal of Sciences: Basic and Applied Research (IJSBAR), 36(2), 145-170. https://core. ac.uk/download/pdf/249336091.pdf

Gillmore, M., Lewis, S., Lohr, M., Spencer, M., \& White, R. (1997). Repeat pregnancies among adolescent mothers.Journal of Marriage and Family, 59(3), 536-550. https://doi.org/10.2307/353944

Grundy, E., \& Tomassini, C. (2005). Fertility history and health in later life: A record linkage study in England and Wales. Social Science $\mathcal{E}$ Medicine, 61(1), 217-228. https:// doi.org/10.1016/j.socscimed.2004.11.046
Gyan, C. (2013). The effects of teenage pregnancy on the educational attainment of girls at Chorkor, a suburb of Accra. Journal of Educational and Social Research, 3(3), 53. https://doi.org/10.5901/jesr.2013. v4n3p53

Gyesaw, N. Y. K., \& Ankomah, A. (2013). Experiences of pregnancy and motherhood among teenage mothers in a suburb of Accra, Ghana: A qualitative study. International Journal of Women's Health, 5, 773. https://doi.org/10.2147/ IJWH.S51528

Hermann, J. W. (2006). The voices of teen mothers: The experience of repeat pregnancy. MCN: The American Journal of Maternal/Child Nursing, 31(4), 243249. https://doi.org/10.1097/00005721200607000-00009

Herrin, A. N. (2016). Education, earnings and health effects of teenage pregnancy in the Philippines. United Nations Population Fund.

James, S., Van Rooyen, D., \& Strümpher, J. D. (2012). Experiences of teenage pregnancy among Xhosa families. Midwifery, 28(2), 190-197. https://doi.org/10.1016/j. midw.2011.04.003

Kalmuss, D. S., \& Namerow, P. B. (1994). Subsequent childbearing among teenage mothers: The determinants of a closely spaced second birth. Perspectives on Sexual and Reproductive Health, 26(4), 149. https://doi.org/ 10.2307/2136238

Lavin, C., \& Cox, J. E. (2012). Teen pregnancy prevention: Current perspectives. Current Opinion in Pediatrics, 24(4), 462-469. https://doi.org/ 10.1097/ MOP.0b013e3283555bee

Lehana, T. V., \& Van Rhyn, L. (2003). A phenomenological investigation of experiences of pregnancy by unmarried adolescents in Maseru. Health $S A$ Gesondheid, 8(1), 26-38. https://doi. org/10.4102/hsag.v8i1.113 
Maravilla, J. C., Betts, K. S., \& Alati, R. (2017). Factors influencing repeated teenage pregnancy: A review and metaanalysis. American Journal of Obstetrics and Gynecology, 217(5), 527-545. https:// doi.org/10.1016/j.ajog.2017.04.021

Mkhwanazi, N. (2010). Understanding teenage pregnancy in a post-apartheid South African township. Culture, Health $\mathcal{E}$ Sexuality, 12(4), 347-358. https://doi. org/10.1080/13691050903491779

Mollborn, S., \& Jacobs, J. (2012). “We'll figure a way": Teenage mothers' experiences in shifting social and economic contexts. Qualitative Sociology, 35(1), 23-46. https:// doi.org/10.1007/s11133-011-9213-1

Montgomery, K.S. (2002). Planned adolescent pregnancy: What they wanted. Journal of Pediatric Health Care, 16(6), 282-289. https://doi.org/10.1067/mph.2002.122083

Morales, I. (2013, July 09). Number of Pinay teenagers giving birth up by more than 60 percent in 10 years, 3rd highest in ASEAN. Retrieved February 24, 2019, from https:// www.gmanetwork.com/news/lifestyle/ healthandwellness/316613/ number-ofpinay-teenagers-giving-birth-up-bymore-than-60-percent-in-10years- 3rdhighest-in-asean/story/

Morrell, R., Bhana, D., \& Shefer, T. (2012). Books and babies: Pregnancy and young parents in schools. HSRC Press.

Mphatswe, W., Maise, H., \& Sebitloane, M. (2016). Prevalence of repeat pregnancies and associated factors among teenagers in KwaZulu-Natal, South Africa. International Journal of Gynecology $\mathcal{E}$ Obstetrics, 133(2), 152-155. https://doi. org/10.1016/j.ijgo.2015.09.028

Natividad, J. (2014). Teenage pregnancy in the Philippines: Trends, correlates and data sources. Journal of the ASEAN Federation of Endocrine Societies, 28(1), 30. Retrieved from https://asean-endocrinejournal.org/ index.php/JAFES/article/view/49
Ngabaza, S. (2011). Positively pregnant: Teenage women's experiences of negotiating pregnancy with their families. Agenda, 25(3), 42-51. https://doi. org/10.1080/10130950.2011.610985

Palacios, J., \& Kennedy, H. P. (2010). Reflections of Native American teen mothers. Journal of Obstetric, Gynecologic $\mathcal{E}$ Neonatal Nursing, 39(4), 425-434.https:// doi.org/10.1111/j.1552-6909.2010.01149.x

Penman-Aguilar, A., Carter, M., Snead, M. C., \& Kourtis, A. P. (2013). Socioeconomic disadvantage as a social determinant of teen childbearing in the US. Public Health Reports, 128(2_suppl1), 5-22. https://doi. org/10.1177\%2F00333549131282S102

Raneri, L. G., \& Wiemann, C. M. (2007). Social ecological predictors of repeat adolescent pregnancy. Perspectives on Sexual and Reproductive Health, 39(1), 3947. https://doi.org/10.1363/3903907

Rowlands, S. (2010). Social predictors of repeat adolescent pregnancy and focussed strategies. Best Practice $\mathcal{E}$ Research Clinical Obstetrics E Gynaecology, 24(5), 605-616. https://doi.org/10.1016/j. bpobgyn.2010.02.016

Santelli, J. S., Song, X., Garbers, S., Sharma, V., \& Viner, R. M. (2017). Global trends in adolescent fertility, 1990-2012, in relation to national wealth, income inequalities, and educational expenditures. Journal of Adolescent Health, 60(2), 161-168. https:// doi.org/10.1016/j.jadohealth.2016.08.026

Sedgh, G., Finer, L. B., Bankole, A., Eilers, M. A., \& Singh, S. (2015). Adolescent pregnancy, birth, and abortion rates across countries: Levels and recent trends. Journal of Adolescent Health, 56(2), 223-230. https://doi.org/10.1016/j. jadohealth.2014.09.007

Singh, S., \& Darroch, J. E. (2000). Adolescent pregnancy and childbearing: Levels and trends in developed countries. Family Planning Perspectives, 3, 14-23. https://doi. org/10.2307/2648144 
Sonfield, A., Hasstedt, K., Kavanaugh, M. L., \& Anderson, R. (2014). The social and economic benefits of women's ability to determine whether and when to have children. Guttmacher Institute.

Van Zyl, L., van Der Merwe, M., \& Chigeza, S. (2015). Adolescents' lived experiences of their pregnancy and parenting in a semi-rural community in the Western Cape. Social Work, 51(2), 151-173. https:// doi.org/10.15270/51-2-439

Wickrama, K. A. S., \& Lorenz, F. O. (2002). Women's status, fertility decline, and women's health in developing countries: Direct and indirect influences of social status on health. Rural Sociology, 67(2), 255-277. https://doi. org/10.1111/j.1549-0831.2002.tb00103.x

Wilson-Mitchell, K., Bennett, J., \& Stennett, R. (2014). Psychological health and life experiences of pregnant adolescent mothers in Jamaica. International Journal of Environmental Research and Public Health, 11(5), 4729-4744. https://doi. org/10.3390/ijerph110504729 